\title{
An improved method for detecting $Y$ chromosomal DNA
}

\author{
John R.D. Stalvey and Robert P. Erickson
}

Division of Pediatric Genetics, Department of Pediatrics and Communicable Diseases, and Department of Human Genetics, University of Michigan School of Medicine, Ann Arbor, MI 48109-0618, USA

\begin{abstract}
Summary. The DNA probe Y97 was derived from a repeat sequence in the human $\mathrm{Y}$ centromere, a region which must be present in a mitotically functional $Y$ chromosome. We have demonstrated that $\mathrm{Y} 97$, which detects a Y-specific $5.5-\mathrm{kb}$ $E c o$ RI fragment by Southern analysis, is very useful for the molecular detection of small amounts of Y-derived material and represents a significant improvement over previous tests for molecular diagnosis of sex. The male-female difference in hybridization was unequivocal even when only $25 \mathrm{ng}$ of total DNA was used per lane. Furthermore, in mixing experiments the 5.5-kb Eco RI fragment was detectable even when only $5 \%$ of the total DNA was male. By increasing hybridization stringency, we have developed a rapid, sensitive, and accurate method to detect $\mathrm{Y}$ chromosomal DNA in unrestricted samples.
\end{abstract}

\section{Introduction}

The availability of repeat sequences relatively specific to the $Y$ chromosome has aided development of techniques for molecular detection of Y-derived material (Lau et al. 1984; Lau and Schonberg 1984; Lau 1985; Disteche et al. 1984; McDonough et al. 1986). Several groups have reported the determination of sex of origin in small samples of genomic DNA by using DNA probes containing repeat sequences derived from the heterochromatic region of the $\mathrm{Y}$ chromosome long arm. Lau et al. (1984) used a 3.4-kbHae III fragment to develop a simple screening test for sex diagnosis. This molecular technique was more rapid and required smaller amounts of tissue than a karyotype analysis (Lau et al. 1984). The use of a probe specific to the heterochromatic region of the $\mathrm{Y}$ would be of limited use, however, for molecular diagnosis of patients with a marker chromosome lacking this region. Furthermore, the occasional absence of the heterochromatic region of the Y chromosome in normal, fertile males and the presence of the heterochromatic region in some aparently normal females further confounds the use of the HaeIII probe for molecular diagnosis of sex.

The DNA probe $\mathrm{Y} 97$ contains sequences from a human alphoid centromeric repeat family and detects a $Y$-specific 5.5$\mathrm{kb} E c o$ RI repeat sequence by Southern analysis (Wolfe et al. 1985). In situ hybridization confirms the localization of sequences detected by $\mathrm{Y} 97$ to the centromeric region of the $\mathrm{Y}$ chromosome (Wolfe et al. 1985). Thus, Y97 should be useful for detecting the presence of $\mathrm{Y}$ chromosome, even in individu-

Offprint requests to: R.P. Erickson als possessing a $\mathrm{Y}$ chromosome lacking normal structural characteristics, such as the heterochromatic region. We now report the development of conditions for the reliable use of Y97 to detect small amounts of Y-derived chromosomal material and for rapid "sexing" of human DNA.

\section{Materials and methods}

Cosmid Y97 was originally isolated from a partial human $\mathrm{Y}$ chromosomal library (Wolfe et al. 1985) and was used to detect a 5.5-kb Eco RI fragment characteristic of the alphoid centromeric repeat in the human Y chromosome. The human Alu-repeat sequence probe pBLUR11, which is found in both male and female DNA in equal abundance (Rubin et al. 1980), was used to estimate total DNA in slot blot samples.

Human genomic DNA was prepared from whole blood by standard procedures (Maniatis et al. 1983). Aliquots of DNA were incubated with the restriction enzyme Eco RI at $4 \mathrm{U} / \mu \mathrm{g}$ overnight at $37^{\circ} \mathrm{C}$ (as suggested by Bethesda Research Laboratories, Gathesburg, MD). Fragments were separated by electrophoresis in $0.9 \%$ agarose gels containing $0.0002 \%$ ethidium bromide. Samples were transferred to nitrocellulose. The filters were prehybridized and hybridized at $52^{\circ} \mathrm{C}$ in $50 \%$ formamide, $1.0 \mathrm{M} \mathrm{NaCl}, 1.0 \%$ SDS. The probe was nicktranslated to a specific activity of $5 \times 10^{8} \mathrm{cpm} / \mu \mathrm{g}$. Filters were washed to a final stringency of $0.5 \times \mathrm{SSC}$ at $65^{\circ} \mathrm{C}$ and were exposed for $6 \mathrm{~h}$ to 4 days to Kodak XAR film at $-70^{\circ} \mathrm{C}$ with intensifying screens (Dupont Cornex Lightening-Plus).

For slot blots, unrestricted DNA was denatured and aliquots containing $0.5-5.0 \mu \mathrm{g}$ of DNA were applied to a Manifold Slot Blotter (Scheicher and Schuell, Keene, N.H.). The nitrocellulose filters were prehybridized in $50 \%$ formamide, $1.0 \mathrm{M} \mathrm{NaCl}, 1.0 \% \mathrm{SDS}$ at $52^{\circ} \mathrm{C}$ for Y97. Filters were washed to a final stringency of $0.2 \times \mathrm{SSC}$ at $65^{\circ} \mathrm{C}$ and exposed to Kodak XAR film for $7 \mathrm{~h}$ with or without intensifying screens. After stripping, filters were rehybridized with BLUR11 at $42^{\circ} \mathrm{C}$ and subsequently treated as above. Autoradiographic films of slot blots were scanned using a Zeineh Soft Laser Scanning densitometer (Biomed Instruments Inc., Fullerton, CA). The corrected signal intensity for Y97 was determined by calculating the ratio of peak height for $\mathrm{Y} 97$ bands to peak height for BLUR11 bands for each sample.

\section{Results}

When Y97 was hybridized to Eco RI restricted female and male DNA, only lanes containing male DNA were positive for 


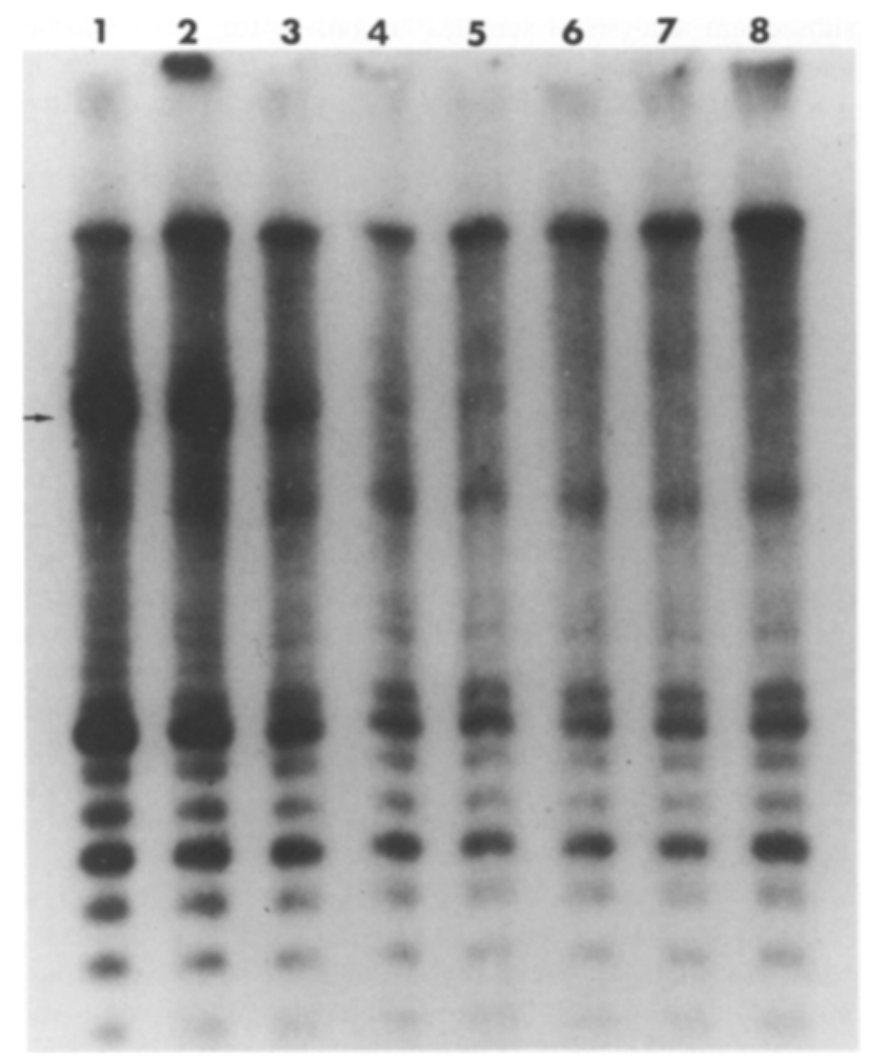

Fig.1. Hybridization of male DNA in mixtures of Eco RI restricted male and female DNA with Y97. Each lane contains $5 \mu \mathrm{g}$ DNA. Lane 1, 100\% male; lane 2, 50\% male; lane 3, 20\% male; lane 4, $10 \%$ male; lane 5, 5\% male; lane 6, 2\% male; lane 7, $1 \%$ male; lane 8 , $100 \%$ female. Y 97 was nick-translated to $5 \times 10^{8} \mathrm{cpm} / \mu \mathrm{g}$; hybridization was performed as described in "Methods"; and exposure was $1 \mathrm{~h}$

the 5.5-kb Eco RI fragment. The male-female difference in hybridization was unequivocal, even at an amount of DNA as low as $25 \mathrm{ng}$ total DNA per lane, indicating sufficient sensitivity to detect $Y$-derived sequences in small samples or in a minor cell line (data not shown). The ability to detect Y-specific sequences in the presence of female DNA, a potential situation if the probe is used to study Turner syndrome mosaics, reconstitution in bone marrow recipients, or amniotic cells, was tested by hybridization of Y97 with different mixtures of EcoRI restricted male and female DNA (Fig. 1). Aliquots of male and female DNA were mixed in varying proportions so that $5 \mu \mathrm{g}$ total DNA were pipetted per slot. Some slots apparently received less than $5 \mu \mathrm{g}$ DNA, yet Y97 detected the male-specific band in the presence of excess female DNA. Although the band was quite faint, the 5.5-kb Eco RI fragment was detected even when male DNA constituted as little as $5 \%$ of the mixture, making this a useful probe for detecting Y material even in low percentage mosaics.

A rapid and simple sex diagnosis procedure for blotted, unrestricted male and female DNA was developed using Y97. When hybridization was carried out at $42^{\circ} \mathrm{C}$ in $50 \%$ formamide and filters were washed to different stringencies, unrestricted male DNA was not distinguishable from unrestricted female DNA. However, when hybridization stringency was increased, Y97 could be used to distinguish between unrestricted male and female DNA in slot blots. The most striking difference occurred when hybridization was carried out at

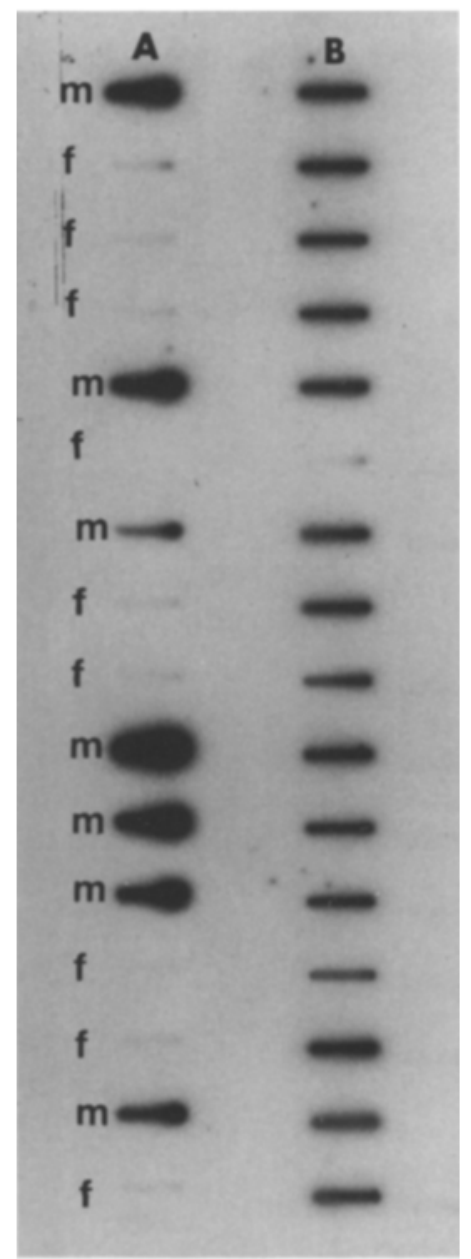

Fig. 2. Hybridization of unrestricted human DNA with Y97 and BLUR11 in a representative slot blot. In column $A, 5-\mu \mathrm{g}$ samples of unrestricted human DNA were hybridized with $\mathrm{Y} 97$ in $50 \%$ formamide, $1.0 \mathrm{M} \mathrm{NaCl}, 1 \% \mathrm{SDS}$ at $52^{\circ} \mathrm{C}$ for $16 \mathrm{~b}$; washed to $0.2 \times \mathrm{SSC}$ at $65^{\circ} \mathrm{C}$; and exposed for $7 \mathrm{~h}$ with an intensifying screen. Samples in column $B$ are the same samples as in column $A$ except that filters were stripped and rehybridized with pBLUR 11 at $42^{\circ} \mathrm{C}$ and exposed for $3 \mathrm{~h}$ without an intensifying screen

$52^{\circ} \mathrm{C}$ in $50 \%$ formamide and $1.0 \mathrm{M} \mathrm{NaCl}$. Duplicate slots were prepared with blind-coded samples of either male or female DNA and hybridized with either the Y97 or pBLUR11 probes. A representative blot is shown in Fig. 2. After hybridization with Y97, slots containing male DNA gave markedly more intense signals than those containing female DNA (Fig. 2, column A). After stripping, rehybridization with the Alu-repeat probe pBLUR11 gave approximately equal strength signals for all but one sample, which was not included in the analysis (Fig. 2, column B). A scanning laser densitometer was used to quantify the intensity of each signal (Table 1). To correct for slight differences in the amount of DNA applied for each sample, the ratio of Y97 signal intensity to BLUR11 signal intensity was used. The mean corrected intensity for male DNA was 14-fold greater than that for female DNA. The lowest ratio found in a male was 0.454 , while the highest ratio found in females was 0.072 . Thus, at least a six-fold difference separated the extremes of the two sexes. Similar blots were achieved with 0.5 and $2.0 \mu \mathrm{g}$ DNA; however it was difficult to get accurate densitometry scans on the low signals from fe- 
Table 1. Signal intensity for Y97 hybridized to unrestricted individual samples of male and female DNA in slot blots

\begin{tabular}{lll}
\hline & Male & Female \\
\hline & $0.711^{\mathrm{a}}$ & 0.072 \\
0.836 & 0.048 \\
& 0.454 & 0.065 \\
& 1.042 & 0.043 \\
& 0.972 & 0.072 \\
& 0.836 & 0.048 \\
& & 0.048 \\
\hline $\bar{x}$ & 0.809 & 0.057 \\
\pm SEM & 0.085 & 0.005 \\
\hline
\end{tabular}

${ }^{a}$ Ratio of Y97 signal intensity to BLUR11 signal intensity

male DNA without overexposing male DNA slots. We conclude that $Y 97$ can be used in a rapid and simple test to determine sex of origin for samples of unrestricted DNA.

\section{Discussion}

We have demonstrated that the DNA probe Y97, which contains sequences from an alphoid centromeric repeat family of the human $\mathrm{Y}$ chromosome, is very useful for the molecular diagnosis of sex. When great sensitivity is required, Y97 can be used to detect a male-specific 5.5-kb Eco RI restriction fragment in Southern analysis of a sample containing as little as $25 \mathrm{ng}$ DNA or when as much as a 20 -fold excess of female DNA is present. When a rapid sex diagnosis is required, a simple slot blot of unrestricted DNA can be probed with Y97. However, it is also necessary to assess total DNA with a probe such as BLUR11 to eliminate error due to too little DNA, as exemplified by sample 6, Fig. 2. Previously described tests have similar advantages (Lau et al. 1984; Lau and Schonberg 1984; Lau 1985; Disteche et al. 1984). However, previous tests have used probes to the heterochromatic region of Yq. This region of the $\mathrm{Y}$ is sometimes greatly reduced or occasionally absent in normal males (Bobrow et al. 1971; McKay et al. 1978), is carried as a translocation by 1 in 3000 normal females (Cooke and Noel 1979), and appears to be absent in Turner syndrome mosaics whose marker chromosome is a Y derivative (Fryns et al. 1980; Magenis and Donlon 1982). Thus, the probes to the heterochromatic region of the $\mathrm{Y}$ chromosome long arm have an increased chance for incorrect diagnosis of sex. The use of single copy probes relatively specific to the $Y$ chromosome have also been used for molecular diagnosis of sex. The advantage of one such probe is that it detects a restriction fragment specific to Yp (De Martinville et al. 1984) where the testis-determining factor appears to be located (reviewed by Goodfellow et al. 1985). However, the probe also recognizes sequences specific to the $\mathrm{X}$ chromosome with equal or greater intensity and therefore cannot be used in a simple and rapid test of unrestricted DNA. Furthermore, detection of the Y-specific fragment appeared to be hindered by the presence of greater than $50 \%$ female tissue in mixing experiments (De Martinville et al. 1984). Our use of Y97, a probe to the $\mathrm{Y}$ centromeric region, represents a significant improvement over previous tests. When time is not of the essence, subsequent analysis of samples "negative" for Y97 could be analyzed with probes to $\mathrm{Yp}$ to detect the rare cases, such as $\mathrm{XX}$ males, who have $\mathrm{Y}$ material in the absence of a Y centromeric region (Goodfellow et al. 1985).

The DNA probe $Y 97$ was originally detected by screening a cosmid library of the human Y chromosome with a plasmid containing a sequence from the alphoid centromeric repeat family derived from the X chromosome (Wolfe et al. 1985). Comparison of the 340-bp consensus repeat element from the $X$ probe with several 340- or 170-bp repeat elements of Y97 revealed about $70 \%$ homology (Wolfe et al. 1985). Although we were easily able to detect differences between male and female DNA samples by Southern analysis because of the male-specific 5.5-kb Eco RI fragment, the high degree of homology between the human $\mathrm{X}$ and $\mathrm{Y}$ alphoid repeat sequences originally hampered the use of $\mathrm{Y} 97$ with slot blots of unrestricted DNA. Despite the apparent homology, we were able to alter the hybridization stringency such that hybridization of Y97 to unrestricted DNA gave a 14-fold stronger signal for male than female samples. We are currently exploring the possibility that $\mathrm{Y} 97$ will detect high frequency restriction fragment length polymorphisms associated with the $Y$ centromeric region similar to those recently described for the $\mathrm{X}$ chromosome and chromosome 17, which are recognized by probes containing 170-bp a repeat elements (Willard et al. 1986). Variation among males in the intensity of signals from fragments detected with $\mathrm{Y} 97$ has been noted and is consistently repeatable for each male (J.Wolfe, unpublished; J.R.D. Stalvey and R.P. Erickson, unpublished).

In summary, Y97 is a useful probe for rapid and accurate sexing of human DNA; however, this is not the limit of the technique's usefulness. It can be used to detect small amounts of male DNA in mixtures with female DNA which may be of use in following host versus graft cells with bone marrow or other transplants and in small samples such as amniotic cells or chorionic villi samples. It would also provide an alternative to extensive karyotypic searches for $\mathrm{XO} / \mathrm{XY}$ mosaicism in patients with Turner syndrome, in whom the presence of a $Y$ has important prognostic significance.

Acknowledgements. We wish to thank Carolyn Brodzinski for providing blind coded male and female DNA for slot blot analysis with Y97. This work was partially supported by grant HD 20670 from the NIH.

\section{References}

Bobrow M, Pearson PL, Pike MC, El-Alfi OS (1971) Length variation in the quinacrine-binding segment of human $\mathrm{Y}$ chromosomes of different sizes. Cytogenetics 10:190-198

Cooke HJ, Noel B (1979) Confirmation of Y/autosome translocations using recombinant DNA. Hum Genet $50: 39-44$

De Martinville B, Blakemore KJ, Mahoney MJ, Francke U (1984) DNA analysis of first-trimester chorionic villous biopsies: test for maternal contamination. Am J Hum Genet 36:1357-1368

Disteche C, Luthy I, Haslam DB, Haar D (1984) Prenatal identification of a deleted $\mathrm{Y}$ chromosome by cytogenetics and a $\mathrm{Y}$-specific repetitive DNA probe. Hum Genet 67:222-224

Fryns JP, Pederson JC, Goddeeris P, van den Berghe H (1980) Nonfluorescent $\mathrm{Y}$ chromosome in mixed gonadal dysgenesis with 45,X/46, XY mosaicism. Ann Génét (Paris) 23:54-56

Goodfellow P, Darling S, Wolfe J (1985) The human Y chromosome. J Med Genet 22:329-344

Lau Y-F (1985) Detection of Y-specific repeat sequences in normal and variant human chromosomes using in situ hybridization with biotinylated probes. Cytogenet Cell Genet 39:184-187 
Lau Y-F, Schonberg S (1984) A male-specific DNA probe detects heterochromatin sequences in familial $\mathrm{Yq}$ chromosome. Am J Hum Genet 36:1394-1396

Lau Y-F, Haung JC, Dozy AM, Kan YW (1984) A rapid screening test for antenatal sex determination. Lancet $I: 14-16$

McDonough PG, Tho SP, Trill JJ, Byrd JR, Reindollar RH, Tischfield JA (1986) Use of two different deoxyribonucleic acid probes to detect $\mathrm{Y}$ chromosome deoxyribonucleic acid in subject with normal and altered Y chromosomes. Am J Obstet Gynecol 154: 737-748

McKay RDG, Bobrow M, Cooke HJ (1978) The identification of a repeated DNA sequence involved in the karyotypic polymorphism of the human Y chromosome. Cytogenet Cell Genet 21:19-32

Magenis RE, Donlon T (1982) Non-fluorescent Y chromosomes: Cytogenetic evidence of origin. Hum Genet 60:133-138

Maniatis T, Fritsch EF, Sambrook J (eds) (1983) Molecular cloning: a laboratory manual. Cold Spring Harbor Laboratory, Cold Spring Harbor, NY
Rubin CM, Houck CM, Deininger PL, Friedman T, Schmid CW (1980) Partial nucleotide sequence of the 300-nucleotide interspersed repeated human DBA sequences. Nature 284:372-374

Willard HF, Waye JS, Skolnik MH, Schwartz CE, Powers VE, England SB (1986) Detection of restriction fragment length polymorphisms at the centromeres of human chromosomes by using chromosome-specific $\alpha$ satellite DNA probes: implications for development of centromere-based genetic linkage maps. Proc Natl Acad Sci USA 83:5611-5615

Wolfe J, Darling SM, Erickson RP, Craig IW, Buckle VJ, Rigby PWJ, Willard HFK, Goodfellow PN (1985) Isolation and characterization of an alphoid centromeric repeat family from the human. Y chromosome. J Mol Biol 182:477-485

Received November 11, 1986 / Revised February 3, 1987 